\title{
Indirect signals of spawning aggregations of three commercial reef fish species on the continental shelf of Bahia, east coast of Brazil
}

\author{
Aline Rocha França, George Olavo*
}

\begin{abstract}
Laboratório de Biologia Pesqueira, Programa de Pós-Graduação em Modelagem em Ciências da Terra e do Ambiente, Universidade Estadual de Feira de Santana - UEFS

(Av. Transnordestina S/N, Novo Horizonte, 44036-900, Feira de Santana, Bahia, Brazil)

*Corresponding author: georgeolavo@gmail.com
\end{abstract}

\section{Abstract}

Lutjanus analis (Mutton snapper), Lutjanus jocu (Dog snapper) and Mycteroperca bonaci (Black grouper) are reef fishes of high commercial value, and are among the principal exploited reef resources on the eastern and northeastern coast of Brazil. These species share the habit of forming transient spawning aggregations, predictable in time and space, which leaves them particularly vulnerable. The present study aimed to obtain indirect indicators of periods and places of spawning aggregations for these species, based on the exploratory analysis of available data on commercial catches and fishing efforts in Southern Bahia. Line fishery landings data were monitored in 12 locations in the region, and catch records of Mutton snapper (1320 landings), Dog snapper (654) and Black grouper (1162) were analyzed. A strategy was developed for exploratory analysis of monthly CPUE variation and individual distribution of CPUE per trip. The results showed the occurrence of aggregations in 26 specific sites, with values of relative abundance far above the annual mean, during spring/summer and autumn/winter. The occurrence of these anomalous catches was validated with the fishermen responsible for respective fishing trips. Additional studies are needed to confirm spawning activity at these sites. Analysis of inter-annual variation suggests a decreasing trend in relative abundance of Black grouper and Mutton snapper, possibly associated with unregulated fishing of spawning aggregations.

Descriptors: Mycteroperca bonaci, Lutjanus analis, Lutjanus jocu, Spawning aggregation, Artisanal reef fisheries, snapper.

\section{RESUMO}

Lutjanus analis (Cioba), Lutjanus Jocu (Dentão) e Mycteroperca bonaci (Badejo) são peixes recifais de alto valor comercial e estão entre os principais recursos explotados na costa da Bahia. Estas espécies compartilham o hábito de formar agregações reprodutivas transientes, previsíveis no tempo e no espaço, o que as torna particularmente vulneráveis. $\mathrm{O}$ presente estudo objetivou obter indicadores indiretos de períodos e locais de possível ocorrência de agregações reprodutivas destas espécies, a partir da análise exploratória de dados de captura e esforço de pesca disponíveis para a região do Baixo Sul da Bahia. Foram analisados dados de desembarques da pesca de linha monitorados em 12 localidades da região, com registros de captura de Cioba (1320 desembarques), Dentão (654) e Badejo (1162). Foi desenvolvida uma estratégia de análise exploratória da variação mensal e distribuição individual das CPUE por viagem. Os resultados indicaram ocorrência de agregações em 26 sítios específicos, observando valores de abundância relativa muito acima das médias anuais, tanto no período de primavera/verão, como no de outono/inverno. As ocorrências dessas capturas foram validadas junto aos pescadores responsáveis por tais pescarias. Estudos adicionais são necessários para confirmar a atividade de desova nesses locais. Análise da variação inter-anual das CPUE sugere tendência de declínio na abundância relativa do Badejo e da Cioba, possivelmente associada à pesca não controlada sobre agregações reprodutivas.

Descritores: Mycteroperca bonaci, Lutjanus analis, Lutjanus jocu, Agregação reprodutiva, Pesca artesanal recifal, vermelhos. 


\section{INTRODUCTION}

The three species considered in this study have demersal life habits associated with reef environments: the Mutton snapper Lutjanus analis (CUVIER, 1828), the Dog snapper Lutjanus jocu (BLOCH \& SCHNEIDER, 1801) and the Black grouper Mycteroperca bonaci (POEY, 1860). All three of them are of high commercial value and among the principal resources exploited by fishing activity on the east and northeast coast of Brazil (MARTINS et al., 2006; FRÉDOU, 2004). Together they accounted for $9.4 \%$ of the marine fish production recorded in Bahia state, in 2006 (IBAMA, 2008). These fishes are caught mainly by handline fishing, the primary fishing gear used by artisanal fleets of the state of Bahia for over four centuries (OLAVO et al., 2005). In 2006, the estimated handline fishing landings were of $9,598 \mathrm{t}$, representing $22 \%$ of all state fish production among all types of marine and estuarine fisheries (IBAMA, 2008).

The three species live alone or in small groups from coastal and estuarine zones to outer continental shelfs and upper slope mesophotic reef ecosystems, reaching depths greater than 100 m (HEEMSTRA; RANDALL, 1993; FREDOU; FERREIRA, 2005; CLARO; LINDEMAN, 2008; HINDERSTEIN et al., 2010; OLAVO et al., 2011). They share ecological, biological, and behavioral characteristics, such as the performance of spawning aggregations, which make them particularly vulnerable to unregulated fisheries (DOMEIER; COLIN, 1997; COLEMAN et al., 1999), and offshore mineral exploration and production activities (carbonates and hydrocarbons) which are currently expanding along the Brazilian coast (MARCHIORO et al., 2005; OLAVO et al., 2011). During the reproductive period, which can last for days or weeks, hundreds of fish migrate to specific spawning areas (DOMEIER; COLIN, 1997). These aggregation events are predictable in time and space, and are well known by the artisanal fishermen of Bahia (OLAVO et al., 2005).

A spawning aggregation can be defined as "a group of fish of the same species gathering for spawning purposes, with a density or number of fish significantly higher than that observed in the aggregation area during the non-reproductive period" (DOMEIER; COLIN, 1997). The identification of spawning activity during these aggregations may be assessed by means of two types of signal: direct and indirect (COLIN et al., 2003). Direct signals provide unambiguous evidence of the occurrence of a spawning aggregation. They include direct observation, documentation of courtship behavior, and witnessing the spawning time during scuba diving at spawning sites. Additionally, hydrated oocytes are indicative of imminent spawning, and post-ovulatory follicles on the gonads of females caught in an aggregation are indicative of recent spawning (COLIN et al., 2003).

Indirect signals require additional supporting information to confirm the reproductive character of the aggregation. Examples of indirect signals include a swollen abdomen in the females, a change in the breeding color pattern, or a significant increase in the relative abundance or a sharp rise in commercial catches in certain times of year and fishing areas. In this last case, COLIN et al. (2003) suggested that an increase of at least three times the mean relative abundance or catch rates observed during the non-reproductive period is indicative of a possible spawning aggregation.

SADOVY et al. (2008) estimated that $79 \%$ of the spawning aggregations whose status is known by the Science and Conservation of Fish Aggregations (SCRFA) organization show signs of decline, in addition to records of already extinct aggregations in different regions of the world. In Brazil, the first initiative to systematically survey reef fish spawning aggregations was proposed under the "Pro-Arribada Project: Reef Fish Spawning Aggregation in Brazil". This project originated from an agreement between the national environmental agency IBAMA and the oil and gas industry, involving a multi-institutional network of Brazilian researchers on reef fish ecology and fisheries for implementation. The project was created with the primary goal of supporting the environmental licensing of oil and gas exploration/prospecting and production activities offshore in Brazil. The information generated by the project can also be used in future proposals for reef fisheries management strategies, as well as planning networks of Marine Protected Areas.

The survey and analysis of previous catch data and commercial fishing efforts were the initial steps of the project, following the methodology established by SCRFA (COLIN et al., 2003). This study aims to obtain indirect indicators for the identification of periods and sites of possible occurrence of Mutton snapper (L. analis), Dog snapper (L.jocu) and Black grouper (M. bonaci) spawning aggregations, from the exploratory analysis of catch and effort data available on handline fishing in the southern part of the state of Bahia, Brazil. 


\section{MATERIAL AND METHODS}

\section{DATABASES}

The official fishing statistics available for the state of Bahia present serious inconsistencies regarding the discontinuity and quality of catch data, which are generally underestimated for reef fish, as demonstrated by KLIPPEL et al. (2005a). Furthermore, they are only available by municipality and commercial category of species (MARTINS et al., 2006; FREIRE; OLIVEIRA, 2007; IBAMA, 2008).

In the study area, the southern coast of the state of Bahia between the latitudes of $13^{\circ} 00^{\prime} \mathrm{S}$ and $14^{\circ} 30^{\prime} \mathrm{S}$ (Figure 1), data from Petrobras' Participatory Monitoring of Fishing Activity project are available for the period between March 2005 and August 2009. This project is a consistent source of information on catch and effort of the regional handline fishing. The monitoring project collected data on landings in 12 artisanal fishing communities: Barra Grande, Boipeba, Camamu, Gamboa, Garapuá, Guaibim, Ilha do Contrato, Ilha d'Ajuda, Barra dos Carvalhos, Morro de São Paulo, São Francisco, and Valença. Although this database only contains catch data for commercial species, there is a high and satisfactory correlation between the commercial names and the biological species of the three resources discussed here: Mutton snapper (regionally named Cioba - Lutjanus analis), Dog snapper (Dentão - Lutjanus jocu) and Black grouper (Badejo - Mycteroperca bonaci).

For these species, complementary data are also available from biological sampling obtained by the REVIZEE Program (MMA/SECIRM) from September 1997 to September 1999. These data include information with better taxonomic, biological, and spatial resolution, and the catch data are detailed by biological species, fishing area and sample of length frequencies (COSTA et al., 2005). However, for the study area, these data are restricted to handline catches sampled at the landing ports of Valença. Together, the data from these two sources provide a unique and meaningful set of information about the reef fisheries undertaken in the study area (Table 1).

\section{Data Analysis}

In this analysis, each landing was considered a sampling unit. Only the landings of fishing trips in which the target species of this study were caught were included in the analysis. Communities with less than 30 landings with catch of the target species were disregarded, because the fleets of these communities are targeted to other fishing

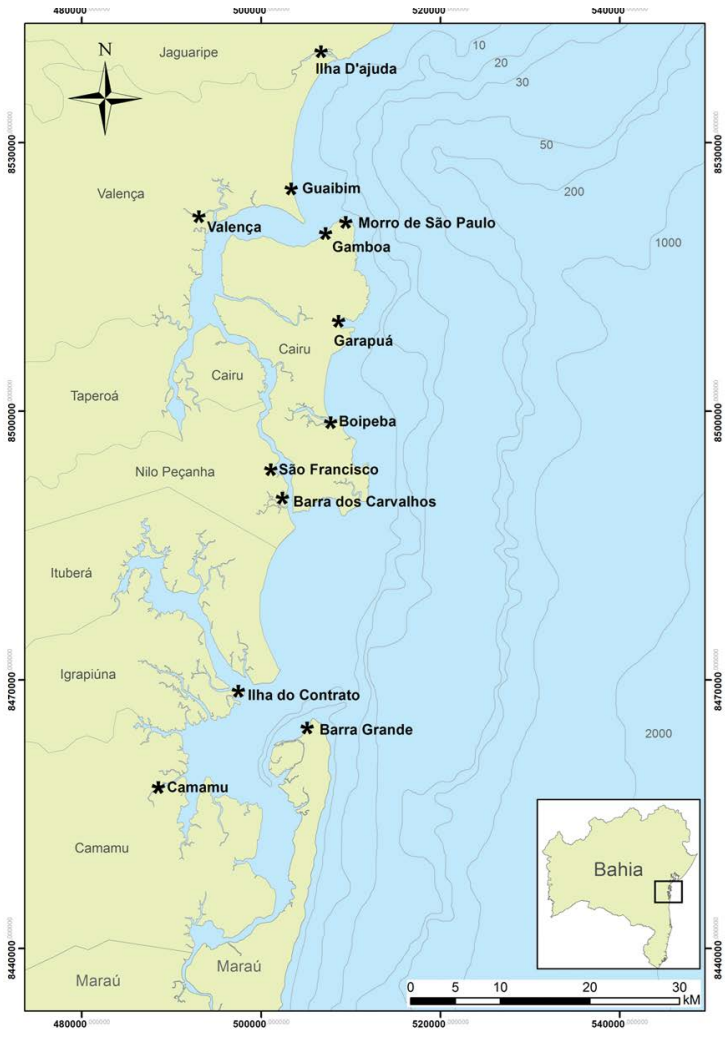

Figure 1. Map of the study area in Southern Bahia, on the eastern Brazilian coast, showing the communities where handline artisanal fleets were monitored in landings ports, between 2005-2009.

resources. For L. analis, the communities of Guaibim and Morro de São Paulo were excluded. For L. jocu, the communities of Garapuá, Ilha d'Ajuda and Morro de São Paulo, and for M. bonaci only the landings of the Ilha d'Ajuda fleet were excluded.

We developed an exploratory analysis strategy from monthly mean (arithmetic mean) variation and distribution of individual catch per unit effort (CPUE) per trip. The CPUE was assumed to be a specific relative abundance index in fishing areas visited during a fishing trip (sampling unit), as demonstrated by COSTA et al. (2005). The CPUE is calculated according to the following equation:

$$
\mathrm{CPUE}=\mathrm{C}_{\mathrm{s}, \mathrm{t}} /\left(\mathrm{F}_{\mathrm{t}} \times \mathrm{D}_{\mathrm{t}}\right)
$$

Where:

$\mathrm{C}_{\mathrm{s}, \mathrm{t}}=$ total catch in $\mathrm{kg}$ of the species (s) on the fishing $\operatorname{trip}(\mathrm{t})$

$\mathrm{F}_{\mathrm{t}}=$ number of fishermen on board during the trip $(\mathrm{t})$

$\mathrm{D}_{\mathrm{t}}=$ duration of the trip $(\mathrm{t})$ in days of effective fishing 
Table 1. Characteristics of data available in the two databases analyzed. Numbers and percentages of the total monitored landings (sampling units) refer to landings with catches of the three target species analyzed for handline fisheries in southern Bahia: Black grouper (Mycteroperca bonaci), Mutton snapper (Lutjanus analis) and Dog snapper (Lutjanus jocu)

\begin{tabular}{|c|c|c|c|c|c|c|c|}
\hline \multirow[t]{2}{*}{ Database } & \multirow[t]{2}{*}{$\begin{array}{l}\text { Monitoring } \\
\text { period }\end{array}$} & \multirow[t]{2}{*}{$\begin{array}{l}\text { Total of fleets monitored } \\
\text { (communities) }\end{array}$} & \multirow[t]{2}{*}{$\begin{array}{l}\text { Total of vessels } \\
\text { monitored }\end{array}$} & \multirow[t]{2}{*}{$\begin{array}{l}\text { Total of landings } \\
\text { monitored }\end{array}$} & \multicolumn{3}{|c|}{$\begin{array}{l}\text { Number and percentage of landings } \\
\text { monitored with catches of the species }\end{array}$} \\
\hline & & & & & L. analis & L. jocu & M. bonaci \\
\hline $\begin{array}{l}\text { Revizee } \\
\text { Program }\end{array}$ & $\begin{array}{l}\text { Sep/1997 to } \\
\text { Oct/1999 }\end{array}$ & 1 & 24 & 148 & $107(72.3 \%)$ & $86(58.1 \%)$ & $68(46.0 \%)$ \\
\hline $\begin{array}{l}\text { Participatory } \\
\text { Monitoring }\end{array}$ & $\begin{array}{c}\mathrm{Mar} / 2005 \text { to } \\
\text { Aug/2009 }\end{array}$ & 12 & 534 & 5588 & $1213(21.7 \%)$ & $568(10.2 \%)$ & $1094(19.6 \%)$ \\
\hline
\end{tabular}

A global mean CPUE by species has been calculated from the monthly CPUE series for the entire period of available data, for each database (Revizee and Petrobras). This overall CPUE was used as the basis for the establishment of threshold criteria that identify possible fish aggregations, considering a level of CPUE three times the global CPUE mean, as suggested by COLIN et al. (2003):

$$
\mathrm{CPUE}_{\text {threshold-criteria }}=3 \times \mathrm{CPUE}_{\text {global mean }}
$$

Considering the wide variation observed in CPUE per trip and the low sensitivity of the global mean due to the occurrence of anomalous records of extremely high CPUE, monthly distributions of individual CPUE per trip were investigated, identifying the provenance (from "where" fishing area, sites of aggregation - and "who" - fisherman, boat, community) of the maximum extreme points, outliers and far outliers observed in the boxplots.

In addition to the monthly distributions of individual CPUE per trip, nonparametric Kruskal-Wallis test statistics were calculated to verify the variation of interannual CPUE.

Boxplots are non-parametric techniques, which show the differences between the data of populations without making any assumptions about the type of statistical distribution (HOAGLIN et al., 1983). A boxplot is a concise way to graphically depict groups of numerical data, using a box that indicates the $25^{\text {th }}$ percentile ( $1^{\text {st }}$ quartile) and $75^{\text {th }}$ percentile ( $3^{\text {rd }}$ quartile) of sample distribution; an internal line that represents the median ( $2^{\text {nd }}$ quartile); and vertical lines (whiskers) adjacent to the box, on the top and bottom, which show the continuity of the distribution up to the maximum and minimum extreme values, respectively. Points external to the distribution are represented here by asterisks (outliers) and small circles (far outliers), which represent data that markedly deviate from other elements of the sample in which they occur (FRY, 2002). It is noteworthy that the outliers and far outliers considered here correspond to values that exceed, respectively, the limits of 1.5 and 3.0 times the interquartile distance from the $1^{\text {st }}$ quartile to the bottom and from the $3^{\text {rd }}$ quartile to the top. The interquartile distance is the amplitude of the boxes of a boxplot, between percentiles $25 \%$ and $75 \%$ (FRY, 2002).

For validation purposes, the veracity of the occurrence of fishing with extremely high catches (CPUE extreme points, outliers and far outliers) was verified with the fishermen responsible for such catches in the communities of Gamboa, Boipeba, Camamu and Barra Grande. This verification occurred through semi-structured interviews with the master fisherman identified in the database. During the interviews, additional information was collected about which species occur in large numbers and in which periods of the year, what the specific locations of aggregation are and why these aggregations occur. This additional information was used for triangulation with monitoring data, and the information obtained from the fisherman immediately checked for concordance with catch peaks recorded in the database.

Fork length (FL) of the target species, measured to the lower centimeter, was also observed in the database of landings from Valença sampled by the REVIZEE Program, as the participatory monitoring database does not include this kind of information.

\section{RESULTS}

The data analyzed showed monthly mean CPUE peaks both during the period of spring/summer oceanographic conditions (September to February), and during the fall/winter period (March to August).

\section{BlaCK GROUPER (MYCTEROPERCA BONACI)}

A total of 1,094 landings with catch of the Black grouper, recorded between 2005-2009, were analyzed. The highest monthly mean CPUE occurred during the autu$\mathrm{mn} /$ winter, between the months from April to September (Figure 2). Less pronounced CPUE peaks were also detected in November and December. 


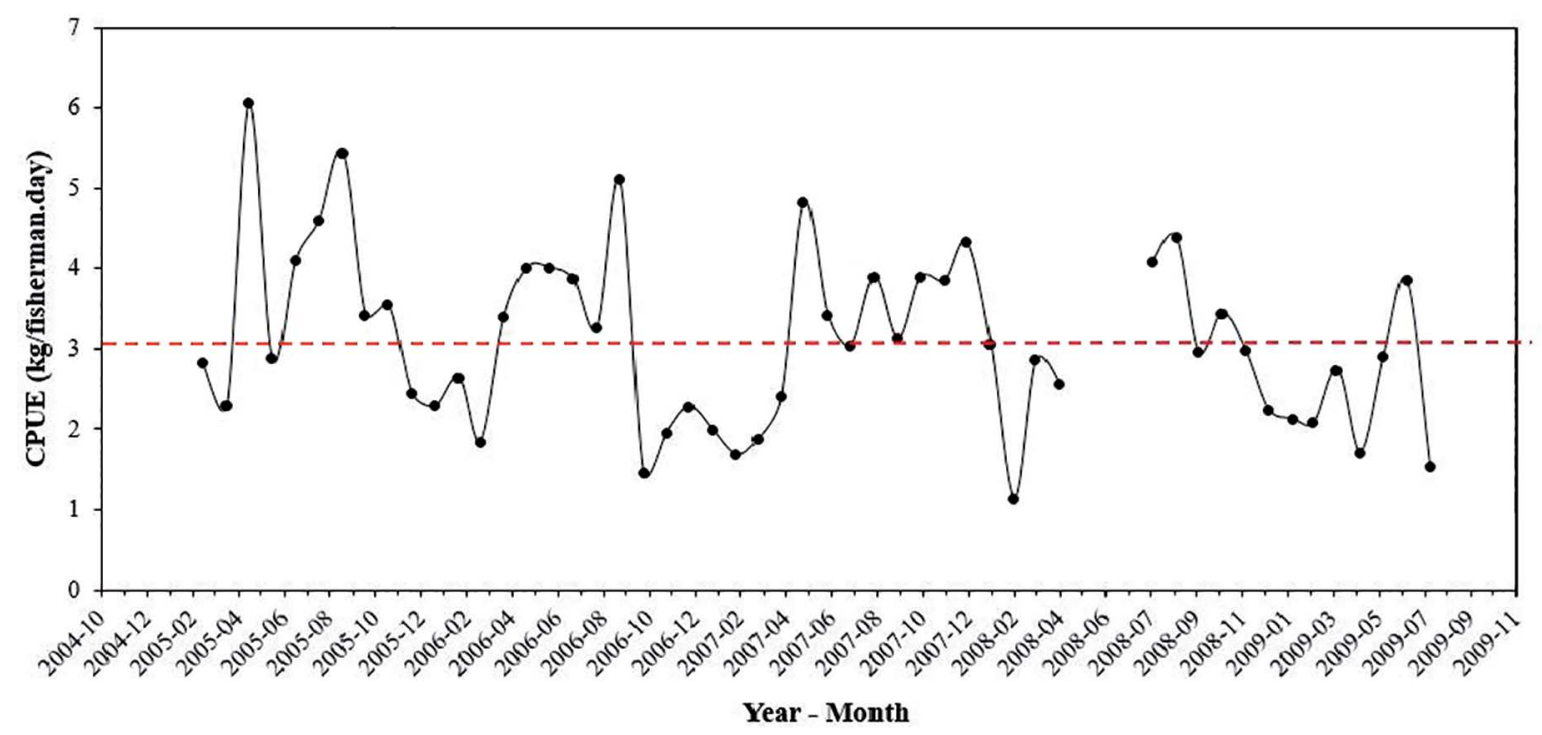

Figure 2. Variation of monthly mean CPUE ( $\mathrm{kg} /$ fisherman.day) for the Black grouper (Mycteroperca bonaci) in the monitored period between 2005 and 2009. The dashed line (-----) indicates the global mean CPUE for the species (3.1 kg/fishermen.day).

Figure 3 shows the boxplot of the distribution of Black grouper individual CPUE per fishing trip (sampled landings) grouped by month (A) and by year (B), for the entire data series (2005-2009). Extreme maximum values (vertical lines) that exceed the threshold criteria of three times the global mean CPUE (9.3 kg/fishermen.day) were observed in May, June and September. These extreme CPUE values can be considered an indirect indicator of Black grouper aggregation in those months, in the light of the criteria proposed by COLIN et al. (2003).

Outliers and far outliers are observed in the CPUE data distribution presented in Figure 3. In particular, the occurrence of far outliers in CPUE of the Black grouper landings monitored, with CPUE values far above the threshold criteria (CPUE of $9.3 \mathrm{~kg}$ /fisherman.day) in May, July to October, and December indicate the possibility that these landings were from catches performed in aggregations. By investigating these outliers and far outliers, it was possible to identify "where" (fishing areas, aggregation sites) the catches had been undertaken (Table 2 and Figure 3).

\section{Mutton SnAPPer (LutJanus ANALIS)}

For Mutton snapper, a total of 1,213 landings with catch of the species were analyzed, for the same time period (2005-2009). During this period, the data revealed a higher mean CPUE in late spring and summer (November to January), and late autumn and winter (April to August) (Figure 4).
Figure 5 shows the boxplot of Mutton snapper CPUE distribution of each fishing trip, grouped by month (A) and by year (B) for the period from 2005 to 2009. Far outliers and outliers can be observed throughout the year, yet they are more pronounced from April to July, far exceeding the value of three times the global CPUE mean (8.4 kg/fisherman.day).

The identification of the landings corresponding to Mutton snapper CPUE with highest values (extremes, outliers and far outliers) above the threshold criteria ( $8.4 \mathrm{~kg}$ /fisherman.day) reveal sites and periods of catches performed on possible aggregations of $L$. analis (Table 2 and Figure 5).

\section{DOG SNAPPER (LUTJANUS JOCU)}

The Dog snapper data set presented a total of 568 landings analyzed. Between 2005-2009, Lutjanus jocu had a monthly mean CPUE distribution similar to that observed for Lutjanus analis, but with higher recordings in autumn (April-May), and less pronounced peaks of relative abundance in September and December (Figure 6).

Figure 7 shows the boxplot of Dog snapper CPUE distribution per fishing trip (sampled landings) grouped by month (A) and by year (B) for the data series from 2005 to $2009(\mathrm{n}=568)$. Extreme maximum CPUE values (vertical lines) are observed in the months of April, July, and September, reaching the CPUE threshold criteria $(8.7 \mathrm{~kg}$ /fisherman.day). Far outliers, above the CPUE 

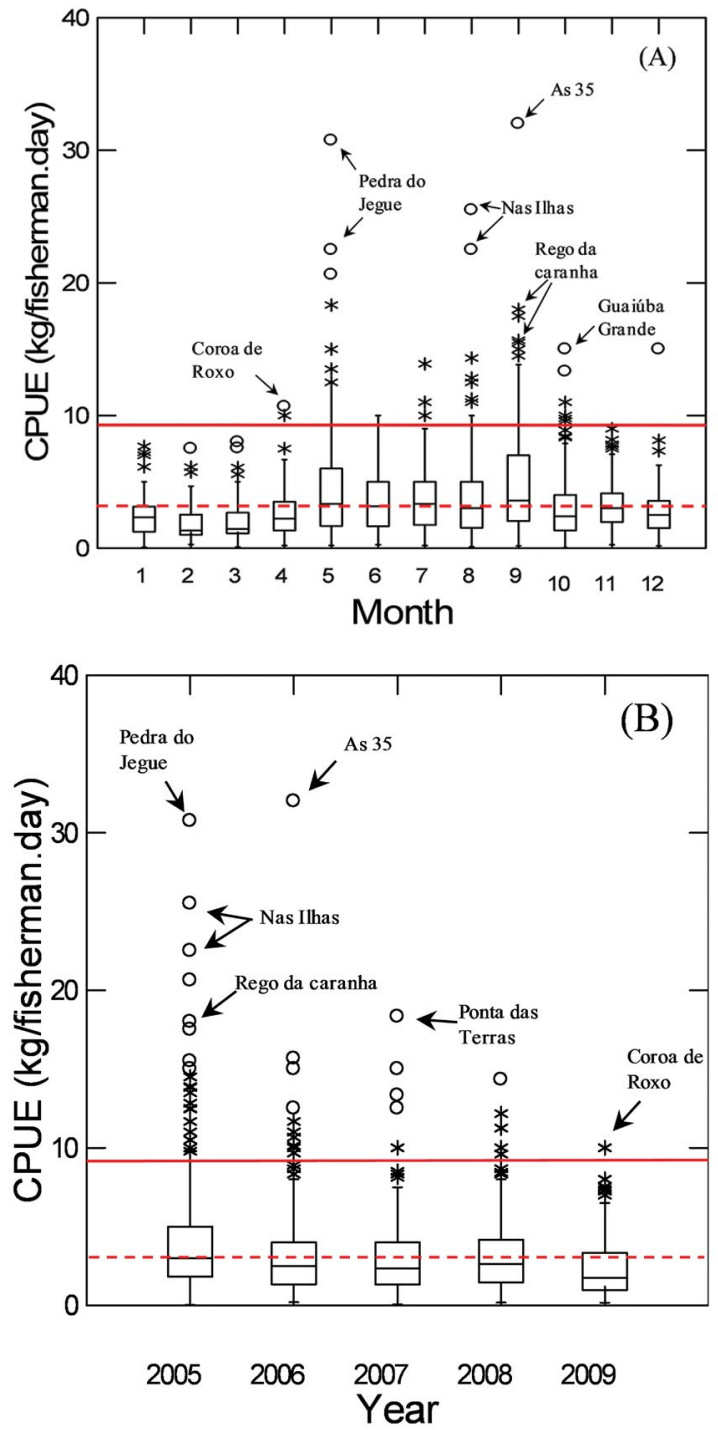

Figure 3. Boxplot with the distribution of Black grouper (M. bonaci) CPUE per trip, grouped by month (A) and by year (B), between 2005-2009 $(n=1,094)$. The dashed line $(----)$ indicates the global mean CPUE for the species $(3.1 \mathrm{~kg}$ /fishermen.day). The solid line (__ indicates the value three times higher than the global mean CPUE $(9.3 \mathrm{~kg} /$ fishermen.day). (*) Represents outliers. (o) Represents far-outliers. The arrows indicate some of the identified potential sites of fish aggregations.

threshold criteria value, are also observed in April to June and October. These extreme CPUE values, outliers and far outliers above the continuous horizontal line (threshold criteria) observed in Figure 7 are indicative of catches carried out on the possible Dog snapper aggregation sites identified in Table 2.

\section{TRADITIONAL FISHERMEN'S KNOWLEDGE AND VALIDATION OF EXTREME CATCHES}

The data corresponding to the extreme catches identified in the CPUE analysis were verified with the fishermen who obtained such abundant catches. Among these, only three records were refuted, all referring to the Dog snapper (L. jocu): one in September 2005, with a landing in Boipeba, and two others in December 2007 and December 2008, with landings in Barra Grande. They were refuted due to the incorrect species identification of the landing, since the interviewees remembered that those were catches of the Cubbera snapper (Lutjanus cyanopterus). The other occurrences were validated by the fishermen, who confirmed the catch levels, periods, and locations of catches performed on aggregations of each of the species in question.

These fishermen call "Arribação" or "Arribada" the periods in wich large catches of the Black groupper, Mutton, and Dog snappers characteristically occur. In all interviews $(n=9)$, the expert fisherman indicated autumn/winter as the period of greatest abundance for the three species, especially the Mutton and Dog snappers, which occur in even greater quantities than the Black grouper in winter. When asked about the reasons for the concentration of such fishes in winter, the majority of interviewees responded that the snappers aggregate for reproductive purposes or migrate to spawn, while for the Black grouper most fishermen did not know the reason for the aggregations (Figure 8).

\section{TREND OF POPULATION DECLINE}

One aspect of great importance that could be observed in this data analysis was the declining trend in CPUE over the last five years, especially for the Black grouper and Mutton snapper. Figure 9 shows the annual variation of mean CPUE of each species discussed in this paper, for the period 2005-2009. The CPUE between years was compared using nonparametric tests, as there was no normal distribution of data when tested by Shapiro-Wilk (ZAR, 2010). There were significant differences between years for each of the three species (Kruskal-Wallis test: $M$. bonaci, $p=2.23 \mathrm{E}-10 ;$ L . analis, $p=0.014 ;$ L. jocu, $p=5.10 \mathrm{E}-05$ ). Pairwise comparison between the years using the MannWhitney statistic revealed significant differences between 2005 and 2009 for $M$. bonaci $(p=8.27 \mathrm{E}-11)$ and $L$. analis $(p=0.005)$; $L$. jocu showed no significant difference between 2005 and $2009(p=0.653)$. 
Table 2. Fishing areas and periods of fishing trips with the highest specific CPUEs (kg/fisherman.day) above the threshold criteria (three times the global mean CPUE) for the Black grouper (Mycteroperca bonaci), Mutton snapper (Lutjanus analis) and Dog snapper (Lutjanus jocu), recorded by the Petrobras participatory monitoring, between 2005-2009, in the study area. The table also shows the species total catch $(\mathrm{kg})$ of the respective fishing trips

\begin{tabular}{|c|c|c|c|c|c|}
\hline Species & Periods of the year & Month & Fishing areas & Total catch & CPUE \\
\hline \multirow{9}{*}{$\begin{array}{l}\text { Black grouper } \\
\text { (Mycteroperca } \\
\text { bonaci) }\end{array}$} & \multirow{3}{*}{ autumn/winter } & May & Pedra do Jegue & 123 & 30.8 \\
\hline & & May & Ponta das Terras & 110 & 18.3 \\
\hline & & August & Nas ilhas & 51 & 25.2 \\
\hline & \multirow{6}{*}{ spring/summer } & September & As 35 & 128 & 32 \\
\hline & & September & Rego da Caranha & 36 & 18 \\
\hline & & September & Guaiúba Grande & 35 & 17.5 \\
\hline & & September & Jequiriçá & 31 & 15.5 \\
\hline & & December & Cabeceira da Lama & 15 & 15 \\
\hline & & September & Nas ilhas & 35 & 17.5 \\
\hline \multirow{5}{*}{$\begin{array}{l}\text { Mutton snapper } \\
\text { (Lutjanus analis) }\end{array}$} & \multirow{3}{*}{ autumn/winter } & May & 35 de Paulo & 300 & 33.3 \\
\hline & & July & Taipú & 100 & 50 \\
\hline & & April & Pedra da Cavala & 281 & 31.2 \\
\hline & \multirow{2}{*}{ spring/summer } & December & Farol do Taipu & 28 & 14 \\
\hline & & October & 35 de Paulo & 25 & 12.5 \\
\hline \multirow{8}{*}{$\begin{array}{l}\text { Dog snapper } \\
\text { (Lutjanus jocu) }\end{array}$} & \multirow{4}{*}{ autumn/winter } & May & 35 de Paulo & 70 & 35 \\
\hline & & May & 35 de Paulo & 328 & 27.3 \\
\hline & & May & Cova da Onça & 800 & 40 \\
\hline & & May & Rebaixa & 25 & 25 \\
\hline & \multirow{4}{*}{ spring/summer } & September & Jequiriçá & 20 & 10 \\
\hline & & December & Cabeceira da Lama & 20 & 10 \\
\hline & & December & Rego da Caranha & 25 & 12.5 \\
\hline & & October & 35 de Paulo & 30 & 15 \\
\hline
\end{tabular}

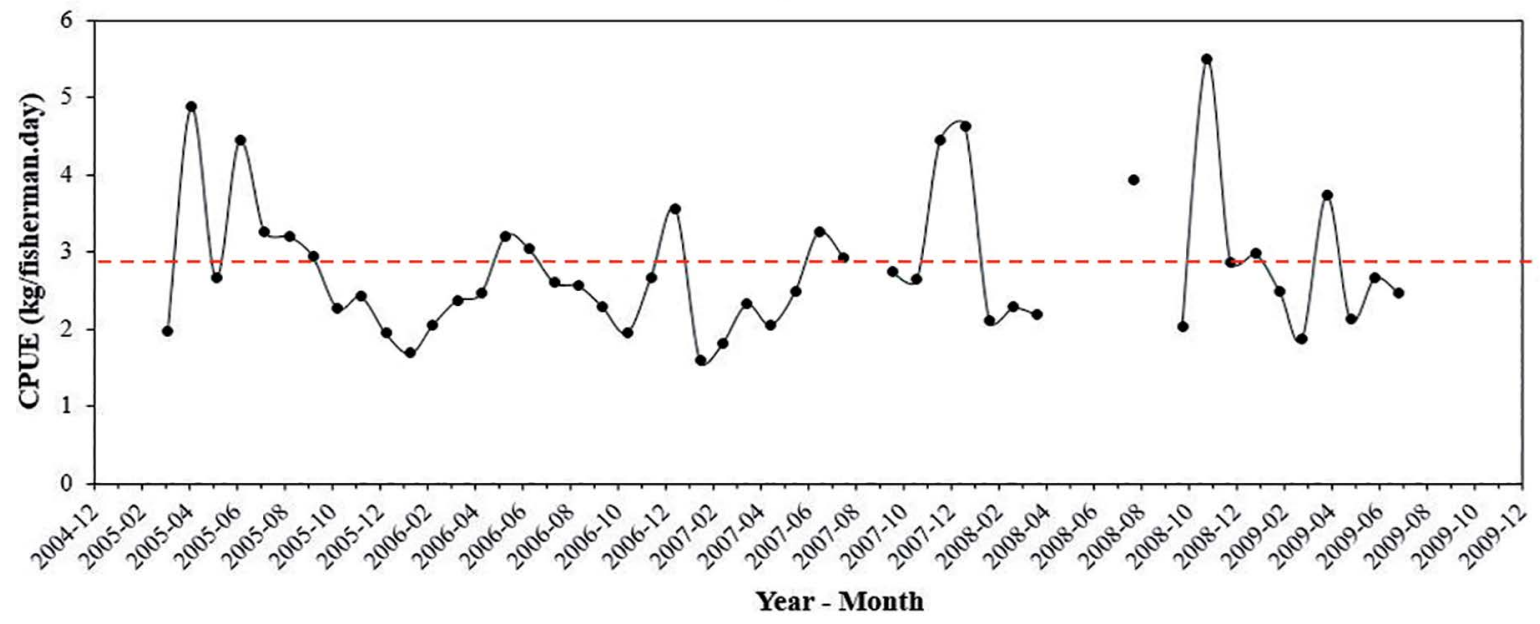

Figure 4. Variation of monthly mean CPUE (kg/fisherman.day) for the Mutton snapper (Lutjnus analis) in the monitored period between 2005 and 2009. The dashed line (-----) indicates the global mean CPUE for the species ( $2.8 \mathrm{~kg} /$ fishermen.day). 

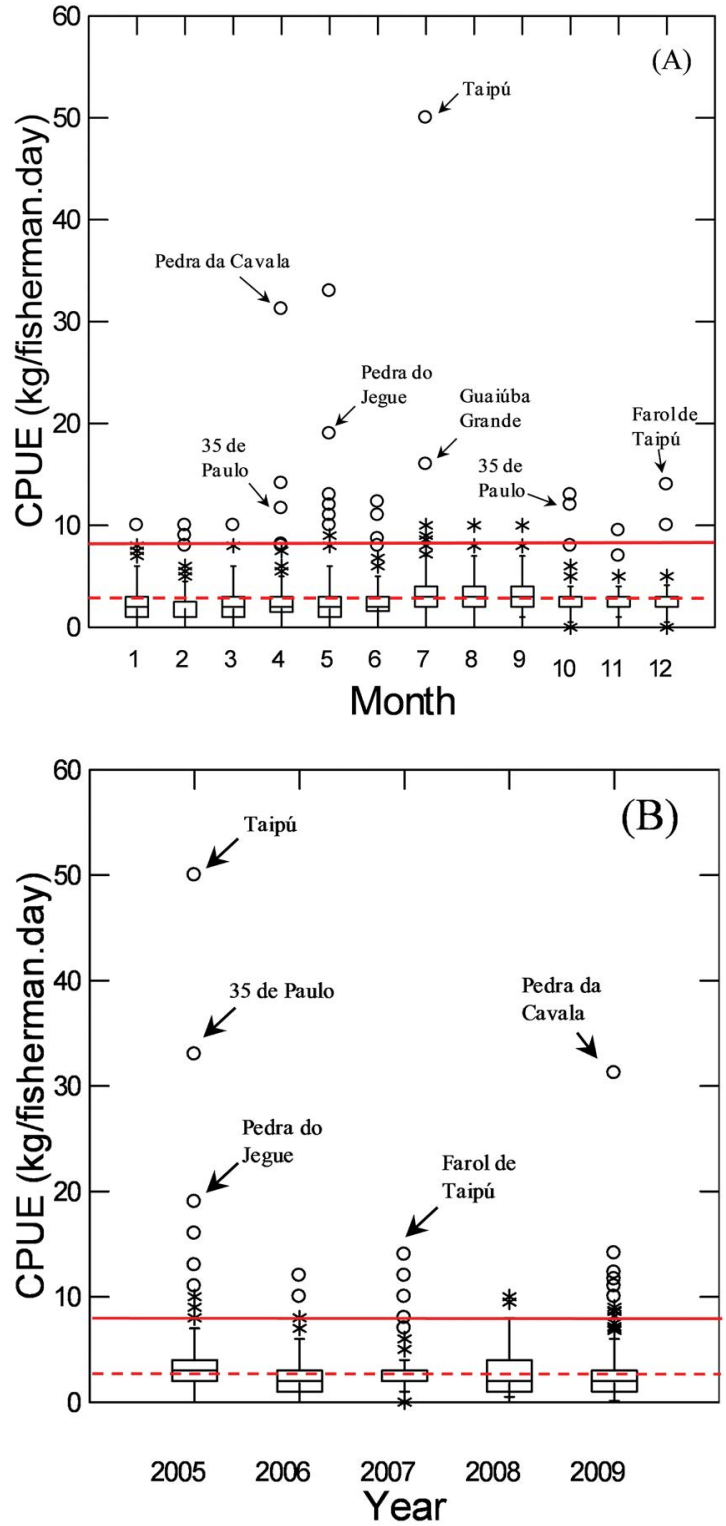

Figure 5. Boxplot with the distribution of Mutton snapper (L. analis) CPUE per trip, grouped by month (A) and by year (B), between 2005 and $2009(\mathrm{n}=1,213)$. The dashed line (----) indicates the global mean CPUE for the species $(2.8 \mathrm{~kg} /$ fishermen.day). The solid line ( indicates the value three times higher than the global mean CPUE ( $8.4 \mathrm{~kg}$ /fishermen.day). (*) Represents outliers. (o) Represents far outliers. The arrows indicate some of the identified potential sites of fish aggregations.

\section{LENGTH VARIATION IN CATCH}

Table 3 presents data of length variation in catch per fishing trip, obtained for landings sampled by the REVIZEE Program in Valença, taking into consideration only the landings with the highest CPUE per trip (extreme CPUE values, outliers and far outliers) recorded for the period 1997-1999.
The maximum CPUE values observed in this data set were, generally, lower than the values recorded in the 2005-2009 specific series. This difference is due to the fact that the REVIZEE sampling program involved only one community of the study area (Valença), over a period of about two years, whereas the data from Petrobras' participatory monitoring includes 11 other communities with significant handline fleets besides Valença, and for a longer monitoring period (five years).

\section{DISCUSSION}

The results indicated the occurrence of possible aggregation processes at least 26 specific sites, both during spring/summer and autumn/winter, identified from values of relative abundance indices (CPUE) at least three times above the global mean CPUE, considering the threshold criteria suggested by COLIN et al. (2003). The identification of extreme CPUE values, outliers, and far outliers provided better indications of potential aggregation sites and periods for the three species evaluated, which may be associated with spawning processes or migration to spawning aggregation sites. BARNETT; LEWIS (1994) reported that the presence of outliers can signify changes in the behavior of a system through deviations in the natural population or increases of elements outside the population examined. As applied to the object of this study, an outlier can signify an acute change in relative abundance of the species, caused by possible concentrations of fish in a given fishing area sampled during the fishing trip, featuring aggregations with or without spawning purposes. Additional studies that focus on these places and periods are needed to confirm the spawning character of these aggregations.

The occurrences of extremely high catches were validated with the fishermen, according to whom the winter aggregations of Mutton snapper and Dog snapper are predominantly due to reproductive activities. Most of the fishermen responded that they did not know the reason for the winter aggregations of Black grouper. However, the second most common response was that the winter aggregations occur because of spawning. The identification of the boats and fishermen who performed these catches has made it possible to begin another research phase, focused on surveying the traditional knowledge of fishermen about the aggregation sites and validate the spawning activity by direct indicators. This phase aims to involve fishermen in the research process and support participatory construction of proposals for fisheries management and strategies 


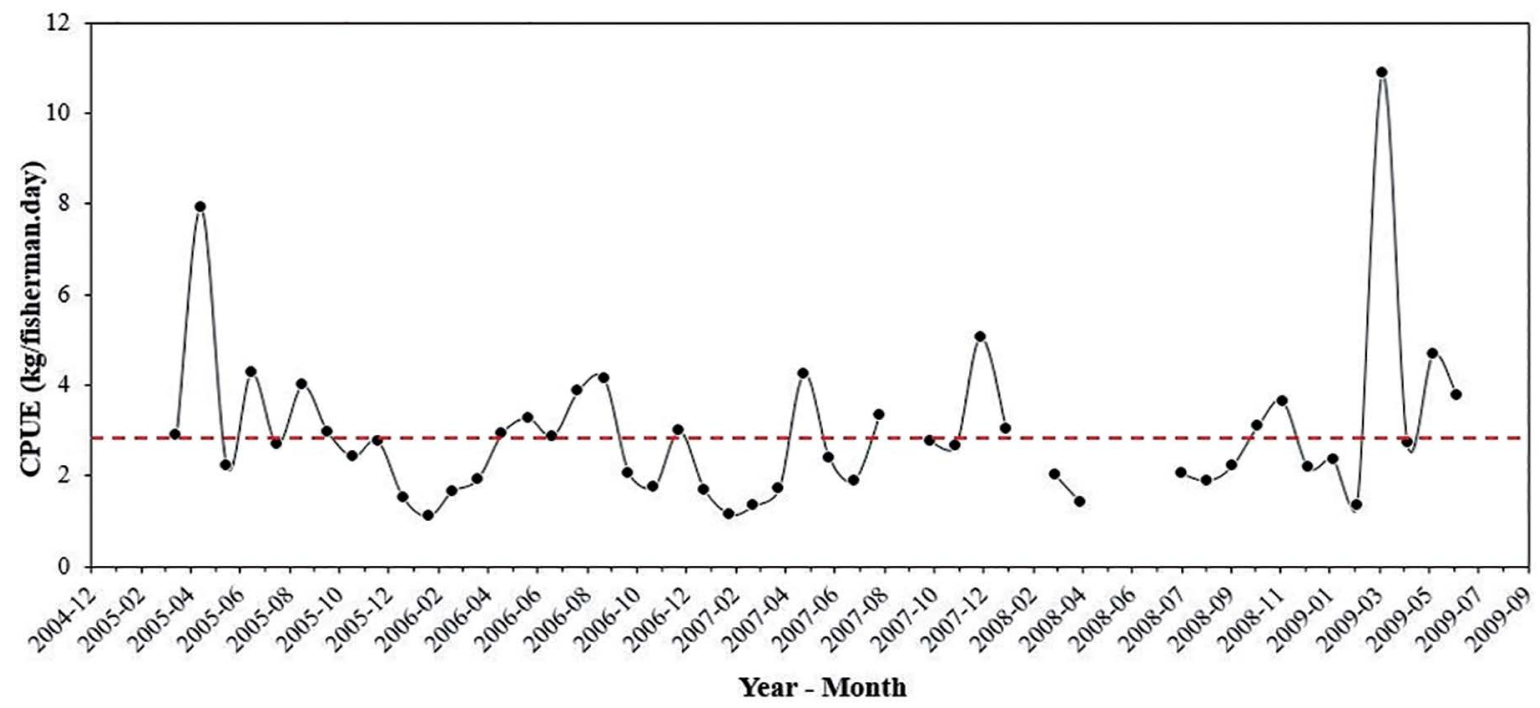

Figure 6. Variation of monthly mean CPUE (kg/fisherman.day) for the Dog snapper (Lutjanus jocu) in the monitored period between 2005 and 2009. The dashed line (-----) indicates the global mean CPUE for the species ( $2.9 \mathrm{~kg} /$ fishermen.day).

for conservation and sustainable use of the regional spawning aggregations (MALAFAIA et al., 2014).

Among the sites observed throughout the monitoring periods (1997-1999 and 2005-2009), the "Coroa de Roxo", "35 de Paulo" and "Rego da Caranha" were the most productive fishing spots, presenting extremely high and recurring significant catch rates for the three species analyzed. These same aggregation sites were described by NUNES (2009) as being among the main fishing areas of the Southern Bahia region, considering the abundance of target reef resources for hook and line fishing. For all the catches of reef fish monitored by the REVIZEE Program in Valença (1997-1999), Lutjanus analis, L. jocu and $M$. bonaci together represented $62.5 \%$ of all catches from "Coroa Roxo", 40.3\% from "Rego da Caranha", and $47.6 \%$ from "35 de Paulo".

The "Coroa Roxo" and "Rego da Caranha" are fishing areas relatively close to each other. Both are about $25 \mathrm{~km}$ from the coastline, while " 35 de Paulo" is about $30 \mathrm{~km}$ further south, at a distance of approximately $13 \mathrm{~km}$ from coastline. These fishing areas are characterized by reef environments associated with geomorphological features of the seabed, such as channels, ravines and biogenic reefs located near the continental shelf break, which, in this area, is about $50 \mathrm{~m}$ deep, or 35 fathoms, as local fishermen often refer to this zone (OLAVO et al., 2005; NUNES, 2009). Not coincidentally, most of the fishing areas identified as aggregation sites in the study area are located on the shelf break, which is generically referred to as "The 35 "
("As 35") or, particularly, as specific fishing spots locally named "35 do Cemitério", "35 do Aguaceiro" or "35 de Paulo", among others " 35 ".

More comprehensively, OLAVO et al. (2011) characterized a shelf edge zone, in a bathymetric range including the shelf break, from $40 \mathrm{~m}$ to $200 \mathrm{~m}$ depth, as an ecotone and priority area for the conservation of reef fish diversity in the south-western Atlantic, in a narrow strip along the continental margin. Increasing attention has been given to the presence of reef formations located on the continental shelf break and upper slope, particularly in the north-western Atlantic (PARKER; MAYS, 1998; SEDBERRY et al., 2004; OLAVO et al., 2007; FRANCINI-FILHO; MOURA, 2008; OLAVO et al., 2011). HINDERSTEIN et al. (2010) discuss the peculiarities of the ecology and management needs of the mesophotic reef ecosystems, especially in tropical shelf edge regions. On the eastern and northeastern Brazilian coast, this zone at the shelf edge has considerable socioeconomic importance and supports important multispecies reef fisheries, concentrating a great part of the handline commercial fishing efforts and production (FREDOU, 2004; COSTA et al., 2005, MARTINS et al., 2005; FREDOU; FERREIRA, 2005; OLAVO et al., 2005). Regional fleets have species of the snapper-grouper complex (COLEMAN et al., 1996) as their main targets.

These species have biological, ecological and behavioral characteristics that make them particularly vulnerable to overexploitation and predatory fishing, as well as degradation and loss of essential habitats for their life 

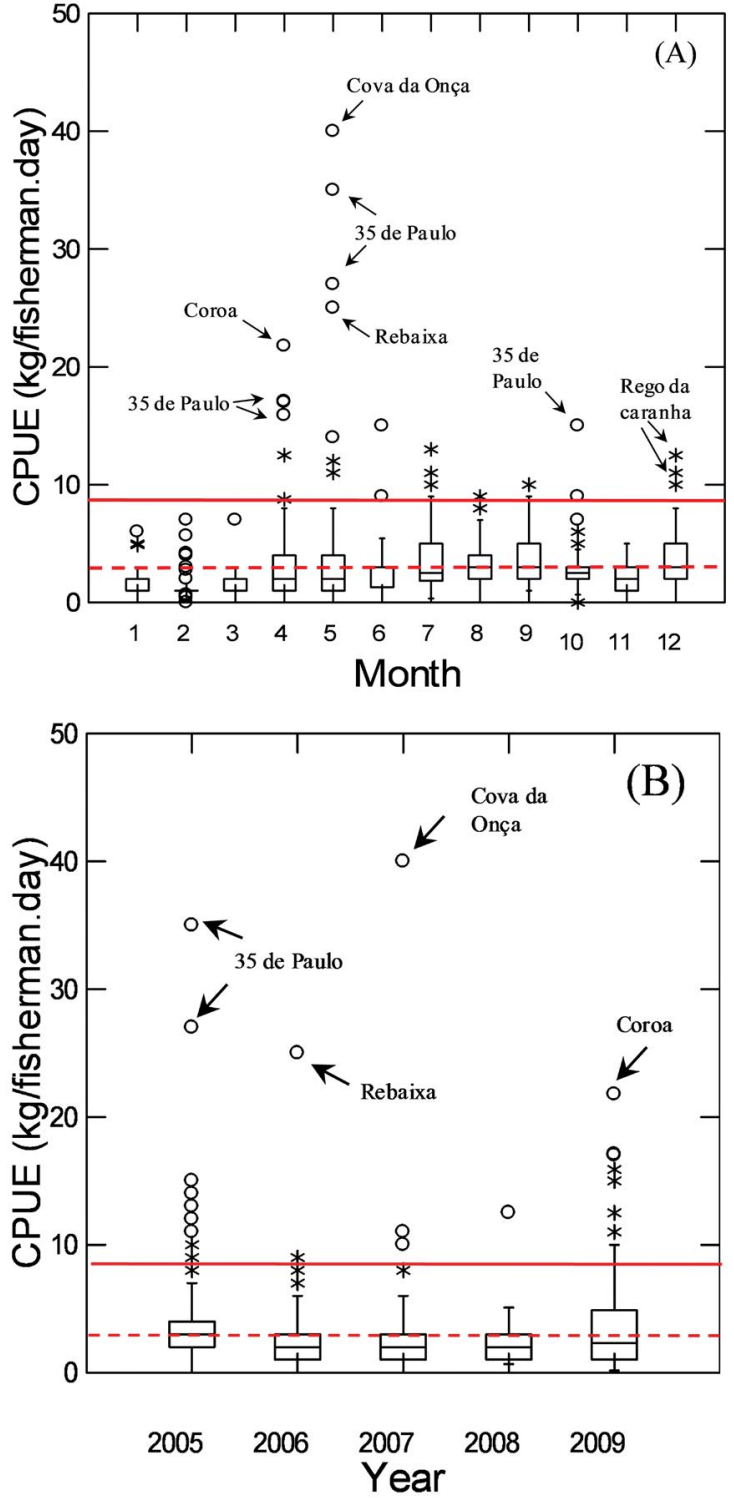

Figure 7. Boxplot with the distribution of Dog snapper ( $L$. jocu) CPUE per trip, grouped by month (A) and by year (B), between 2005 and $2009(\mathrm{n}=568)$. The dashed line (----) indicates the global mean CPUE of ( $2.9 \mathrm{~kg} /$ fishermen.day) for the species. The solid line (_ indicates the value three times higher than the global mean CPUE (8.7 kg/fishermen.day). (*) Represents outliers. (o) Represents far outliers. The arrows indicate some of the identified potential sites of fish aggregations.

history. Such characteristics include low growth rates and natural mortality, high longevity, late sexual maturity, and ontogenetic migrations through habitats of the continental shelf, besides their behavior of spawning in aggregations predictable in time and space (POLOVINA; RALSTON, 1987; COLEMAN et al., 1996; LINDEMAN et al., 2000; SADOVY; CHEUNG, 2003; SADOVY et al., 2008).

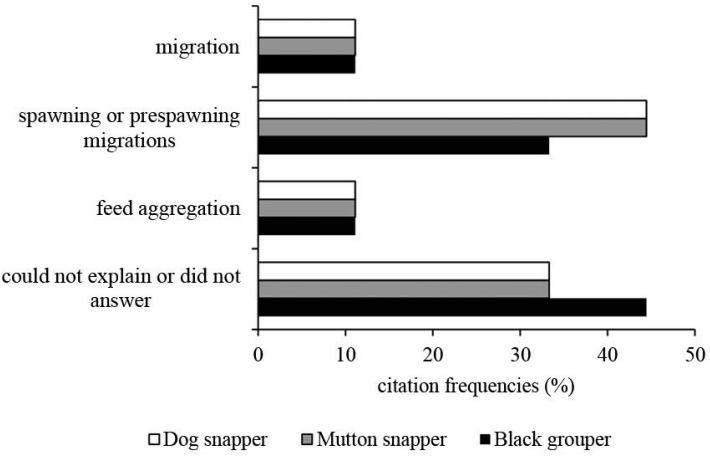

Figure 8. Perception of the reasons for winter aggregations, from main fishermen $(n=9)$ identified as responsible for the largest catches of the Mutton snapper, Dog snapper and Black grouper in the databases available for the study area.
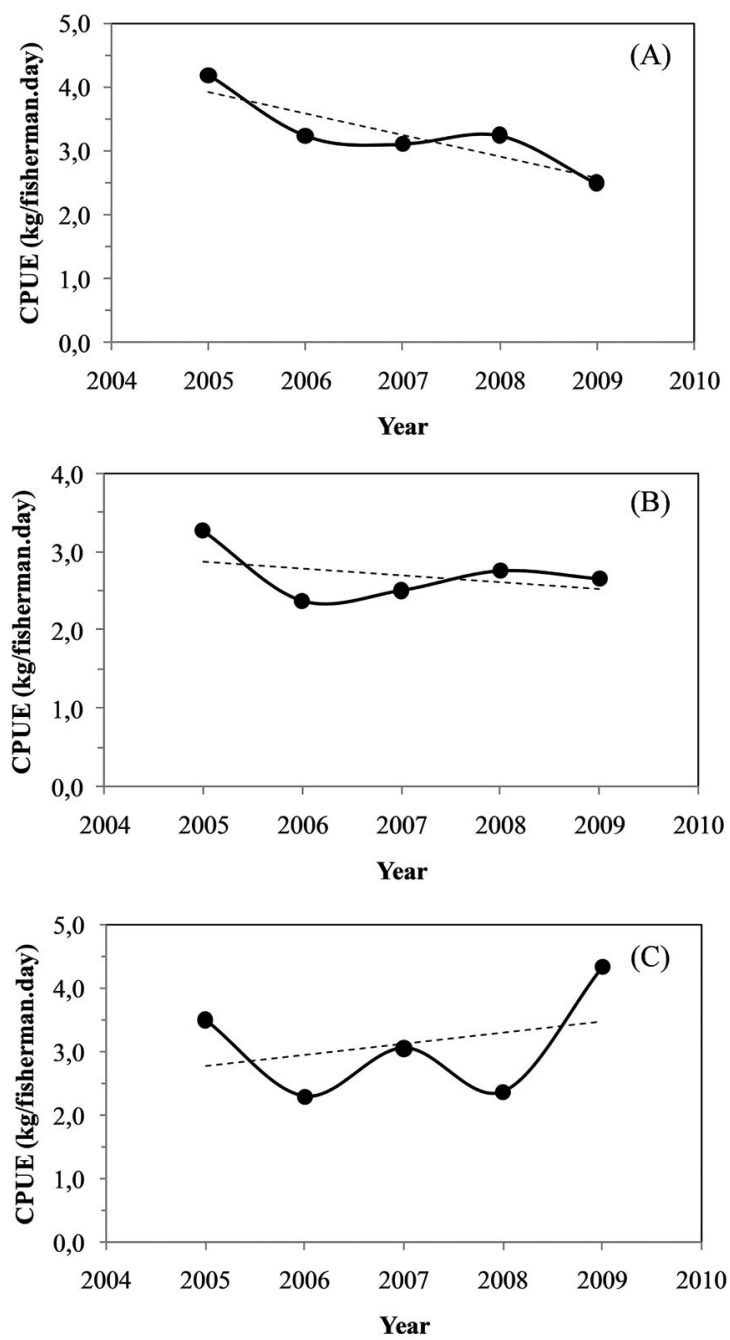

Figure 9. Trends in the annual mean CPUE distribution of Black grouper (A), Mutton snapper (B) and Dog snapper (C) for the handline fishery in the study area, over the period analized from march 2005 to august 2009. 
Table 3. Fork length range (FLmin and FLmax, in $\mathrm{mm}$ ) of catches by species in the landings identified with the highest CPUE (kg/fisherman.day) obtained during the sampling period of REVIZEE Program (1997-1999), in Valença, Southern Bahia. Fishing areas and total catch of species $(\mathrm{kg})$ on each fishing trip sampled on landing, as well as the number of individuals measured and the lengths at first maturity $(\mathrm{L} 50, \mathrm{~mm})$ available in the literature are also presented

\begin{tabular}{|c|c|c|c|c|c|c|c|}
\hline Species & $\begin{array}{l}\text { Periods of } \\
\text { the year }\end{array}$ & Fishing areas & $\mathbf{N}$ & $\begin{array}{l}\text { Total } \\
\text { catch }\end{array}$ & CPUE & FL min. - FL max. & L50 Literature \\
\hline \multirow{7}{*}{$\begin{array}{l}\text { Black grouper } \\
\text { (Mycteroperca } \\
\text { bonaci) }\end{array}$} & \multirow{3}{*}{ autumn/winter } & Rego da Caranha & 10 & 199 & 8 & $690-1210$ & 580 to $951 \mathrm{a}$ \\
\hline & & Coroa de Roxo & 12 & 109.7 & 5.5 & $520-1260$ & \\
\hline & & Coroa de Roxo & 10 & 56.9 & 2.4 & $580-870$ & \\
\hline & \multirow{4}{*}{ spring/summer } & Cova da Onça & 9 & 113 & 5.6 & $720-1180$ & 538 to $659 \mathrm{~b}$ \\
\hline & & Pedra do Jegue & 15 & 114.7 & 4.1 & $500-1040$ & \\
\hline & & Coroa de roxo & 4 & 60 & 3 & $835-1150$ & \\
\hline & & Nas 35 & 9 & 98.4 & 4.9 & $390-1210$ & \\
\hline \multirow{10}{*}{$\begin{array}{l}\text { Mutton snapper } \\
\text { (Lutjanus analis) }\end{array}$} & \multirow{3}{*}{ autumn/winter } & Coroa de Roxo & 99 & 297.8 & 12.4 & $390-720$ & $280 \mathrm{c}$ \\
\hline & & Coroa de Roxo & 60 & 226 & 11.3 & $370-720$ & \\
\hline & & Rego de Caranha & 57 & 196.2 & 7.8 & $390-730$ & \\
\hline & \multirow{7}{*}{ spring/summer } & Subaúma & 88 & 313.5 & 8.7 & $360-700$ & \\
\hline & & Quiepe & 20 & 49.4 & 4.1 & $345-700$ & \\
\hline & & 35 do Cemitério & 9 & 59.2 & 3.9 & $485-685$ & \\
\hline & & Jaguaripe/Caixa Prego & 11 & 36.4 & 3 & $460-750$ & \\
\hline & & Norte & 10 & 40.3 & 3.3 & $520-790$ & \\
\hline & & Pedra da Cavala & 11 & 44.1 & 2.9 & $540-700$ & \\
\hline & & Nas 35 & 5 & 26.3 & 2.2 & $315-660$ & \\
\hline \multirow{5}{*}{$\begin{array}{l}\text { Dog snapper } \\
\text { (Lutjanus jocu) }\end{array}$} & \multirow{2}{*}{ autumn/winter } & Coroa de Roxo & 98 & 362.4 & 15.1 & $330-710$ & $510 \mathrm{~d}$ \\
\hline & & Rego de Caranha & 56 & 229 & 9.2 & $360-720$ & \\
\hline & \multirow{3}{*}{ spring/summer } & Pedra de Pedro/Pedra de Isac & 10 & 31.3 & 3.5 & $470-660$ & 319 to $352 \mathrm{~b}$ \\
\hline & & 35 do Cemitério & 4 & 33.6 & 2.2 & $535-690$ & \\
\hline & & Cova da Onça & 9 & 46.7 & 2.3 & $580-720$ & \\
\hline
\end{tabular}

a: HEEMSTRA; RANDALL (1993); b: FREITAS el al. (2011); c: FERREIRA et al. (2004); d: CLARO; LINDERMAN (2008).

Additional data from the length sampling undertaken by the REVIZEE Program in Valença allow one to ask whether the fish caught during the identified aggregations could have already reached the length of first maturity (L50) when caught. For Black grouper, HEEMSTRA; RANDALL (1993) reported that the range of gonadal maturation length varies between $58 \mathrm{~cm}$ and $95.1 \mathrm{~cm}$, with a mean of $72.1 \mathrm{~cm}$. FREITAS et al. (2011) found a L50 of $63.33 \mathrm{~cm}( \pm 2.57$ $\mathrm{cm})$ for females and $58.14 \mathrm{~cm}( \pm 4.32 \mathrm{~cm})$ for males of this species caught on the Abrolhos Bank. For the aggregations identified in the REVIZEE data series, specimens with lengths equal to or greater than L50 were observed both during the spring/summer and autumn/winter. However, larger fish were observed in autumn/winter. In this same period (autumn/winter), CLARO; LINDERMAN (2003) observed reproductive aggregations of $M$. bonaci in Cuba. TEIXEIRA et al. (2004) reported reproductive peaks of Black grouper in the winter and the phenomenon of "correction" in the summer (this also accounts for an increase in the abundance of catches, but supposedly relates to feeding behavior) for the Northeast of Brazil. FREITAS et al. (2011) identified the period from winter to spring as the reproductive phase of the species with the highest gonadosomatic rates in August and September.

The length of first gonadal maturation of $L$. jocu in Cuba, according to CLARO; LINDERMAN (2008), is $51 \mathrm{~cm}$, given that the highest percentage of mature females is between 60 and $66 \mathrm{~cm}$, and that of males between 57 and $66 \mathrm{~cm}$. FERREIRA et al. (2004) reported mature specimens of $30.2 \mathrm{~cm}$ in the Brazilian Northeast. FREITAS et al. (2011) estimated L50 of $32.42 \mathrm{~cm}( \pm 0.49 \mathrm{~cm})$ for females and $34.42 \mathrm{~cm}( \pm 0.74 \mathrm{~cm})$ for males caught on Abrolhos. By comparing this information with the length of the specimens sampled from catches that occurred in the aggregations identified (observed extreme maximum CPUE), the youngest and most immature fish observed 
(smaller minimum lengths) were seen to be present in the winter. In the spring/summer, the largest fish, already of reproductive size, predominated in the catches. These observations corroborate the findings of FERREIRA et al. (2004) in Northeast Brazil, where mature specimens occurred throughout the year, except in July, and the reproductive peak was observed between January and March. Nevertheless, additional studies are needed to investigate this behavior in the study area.

According to CLARO; LINDERMAN (2008), L. analis sexual differentiation is initiated between 18 and $20 \mathrm{~cm}$, and the juvenile stage, with inactive gonads, extends up to $35-40 \mathrm{~cm}$. In the Northeast of Brazil, in a population of individuals of up to $99 \mathrm{~cm}$, the length at maturity reached $28 \mathrm{~cm}$ (FERREIRA et al. 2004). Given the results obtained from the data available in the study area, it is possible to infer that most specimens collected during the CPUE peak were already within a length range that designates mature fish apt for reproduction, despite the observation of larger fish in the summer.

On analyzing the inter-annual variation of CPUE recorded for the period from 2005 to 2009, and using the Kruskal-Wallis/Mann-Whitney tests, we observed a strong and statistically significant ( $p=8.27 \mathrm{E}-11)$ declining trend in Black grouper relative abundance. The annual mean CPUE recorded for Black grouper in 2009 presented a drop of $41 \%$ in relation to the mean CPUE level observed in 2005. Analysis of long-term trends in fishing catches and yields in the Abrolhos region during the 70 s indicates that Mycteroperca bonaci showed a decreasing tendency in its catches and yields, being replaced by smaller species, such as the Yellowtail snapper (Ocyurus chrysurus), Vermillion snapper (Rhomboplites aurorubens) and Coney (Cephalopholis fulva) in the 90s (COSTA et al., 2005; MARTINS et al., 2005).

For the Mutton snapper, a declining trend in CPUE was also observed (Kruskal-Wallis/Mann-Whitney). In 2009 , it represented about $81 \%$ of the CPUE registered in 2005 (a drop of 19\%). These trends can be corroborated by the stock assessments made by the REVIZEE Program, for the reference year of 1998, already showing that Lutjanus analis was in a state of moderate overexploitation, but Lutjanus jocu was below suitable fishing mortality levels (KLIPPEL et al., 2005b). Official fishing statistics available for the state of Bahia recorded up to 11,160 $\mathrm{t}$ of fish caught by handline fishing in 1998 (27.3\% of the total catch resulting from all forms of fishing). In 2002, this dropped to $14.7 \%$, with an estimated production of only 6,965 t (IBAMA, 2008).
This situation shows cause for concern. The decline may be associated not only with unregulated fishing of reef fish spawning aggregations, but also with the increasing degradation and loss of suitable habitats as detailed by SADOVY et al. (2008) for other spawning aggregations around the world.

\section{ACKNOWLEDGMENTS}

We are grateful to all fishermen from the fishing communities who voluntarily participated in this research. We thank Petrobras for kindly providing data series on catch and fishing effort from the participatory monitoring project of the fishing landings in the study area, and REVIZEE Program (MMA) by the available biological sampling data. This work was incorporated into the Pro-Arribada Project (Reef Fish Spawning Aggregation in Brazil), supported by the Brazilian Biodiversity Fund (FUNBIO) through arrangement with IBAMA and ICMBIO to subsidize the licensing for marine seismic and oil and gas exploration activities off Brazilian coast. Two anonymous reviewers made numerous comments that improved te manuscript.

\section{REFERENCES}

BARNETT, V. \& LEWIS, T. Outliers in Statistical Data. 3ed. New York: John Wiley \& Sons, 1994. 604 p.

CLARO, R.; LINDEMAN, K. C. Spawning aggregation sites of snapper and grouper species (Lutjanidae and Serranidae) on the insular shelf of Cuba. Gulf. Caribbean Res., v. 14, n. 2, p. 91-106, 2003.

CLARO, R.; LINDEMAN, K. C. Biología y Manejo de los Pargos (Lutjanidae) en el Atlántico Occidental. La Habana: Instituto de Oceanología, 2008. 472 p.

COLEMAN, F. C.; KOENIG, C. C.; COLlinS, L. A. Reproductive styles of shallow-water grouper (Pisces: Serranidae) in the eastern Gulf of Mexico and the consequences of fishing spawning aggregations. Environ. Biol. Fishes, v. 47, n. 2, p. 129-141, 1996.

COLEMAN, F. C.; KOENIG, C. C.; EKLUND, A. M.; GRIMES, C. Management and conservation of temperate reef fishes in the Sapper-grouper complex of the southern United States. In: A. MUSICK. (Ed.). Life in the Slow Lane: Ecology and Conservation of Long-Lived Marine Animals. Bethesda: American Fisheries Society, 1999. p. 233-242.

COLIN, P. L.; SADOVY, Y. J.; DOMEIER, M. L. Manual for the Study and Conservation of Reef Fish Spawning Aggregations. Society for the Conservation of Reef Fish Aggregations Special Publication. v.1, n. 1, p.1-98, 2003.

COSTA, P. A. S.; OLAVO, G.; MARTINS, A. S. Áreas de pesca e rendimentos da frota de linheiros na região central da costa brasileira entre Salvador-BA e o Cabo de São Tomé-RJ. In: COSTA, P. A. S.; MARTINS, A. S.; OLAVO, G. (Eds.). Pesca e Potenciais de Exploração de Recursos Vivos na Região Central da Zona Econômica Exclusiva Brasileira. Rio de Janeiro: Museu Nacional, 2005. p. 57-70. 
DOMEIER, M. L.; COLIN, P. L. Tropical reef fish spawning aggregations: defined and reviewed. Bull. Mar. Sci., v. 60, n. 3, p. 698-726, 1997.

FERREIRA, B. P.; REZENDE, S. M.; TEIXEIRA, S. F.; FRÉDOU, T. Lutjanus jocu. In: LESSA, R. P. NÓBREGA, M. F.; BEZERRA JUNIOR, J. L. Dinâmica de Populações e Avaliação de Estoques dos Recursos Pesqueiros da Região Nordeste vol. II. Programa REVIZEE, Subcomitê Regional Nordeste. Recife: Universidade Federal Rural de Pernambuco, 2004.

FRÉDOU, T. The fishing activity on coral reefs and adjacent ecosystems. A case of study of the Northeast of Brazil. Thesis submitted for the degree of Doctor of science in Oceanography. Federal University of Pernambuco. 2004. 218 p.

FRÉDOU, T.; FERREIRA, B. Bathymetric trends of Northern brazilian snappers (Pisces, Lutjanidae): implications for the reef fishery dynamic. Braz. Arch. Biol. Tech., v. 48, n. 5, p. 787-800, 2005.

FREIRE, K. M. F.; OLIVEIRA, T. L. S. Reconstructing catches of marine commercial fisheries for Brazil. Fish. Cent. Res. Rep., v.15, n.2, p. 61-68, 2007.

FREITAS, M. O.; MOURA, R. L.; FRANCINI-FILHO, R. B.; MINTE-VERA, C. V. Spawning patterns of commercially important reef fish (Lutjanidae and Serranidae) in the tropical western South Atlantic. Scientia Marina, v.75, n.1, p. 135-146, 2011.

FRY, J. C. Biological Data Analysis: Practical Approach. New York: Oxford University Press, 2002. 448 p.

HEEMSTRA, P.C.; RANDALL J. E. FAO Species Catalogue. Vol. 16. Groupers of the World (Family Serranidae, Subfamily Epinephelinae) - An annotated and illustrated catalogue of the grouper, rockcod, hind, coral grouper and lyretail species known to date. FAO. Fish. Synop., v. 125, n. 16, p. 382, 1993.

HINDERSTEIN, L. M.; MARR, J. C. A.; MARTINEZ, F. A.; DOWGIALLO, M. J.; PUGLISE, K. A.; PYLE, R. L.; ZAWADA, D. G.; APPELDOORN, R. Introduction to mesophotic coral ecosystems: Characterization, ecology, and management. Coral Reefs, v. 29, p. 247-251, 2010.

HOAGLIN, D. C.; MOSTELLER, F.; TUKEY, J. W. Understanding Robust and Exploratory Data Analysis. New York: John Wiley and Sons, 1983. $447 \mathrm{p}$.

IBAMA. Boletim da Estatística da Pesca Marítima e Estuarina do Nordeste do Brasil - 2006. Tamandaré: CEPENE/ICMBIO, 2008. 385 p.

KLIPPEL, S.; MARTINS, A. S.; OLAVO, G.; COSTA, P. A. S.; PERES, M. B. Estimativas de desembarque da pesca de linha na costa central do Brasil (estados do Espírito Santo e Bahia) para um ano padrão (1997-2000). In: COSTA, P. A. S.; MARTINS, A. S.; OLAVO, G. (Orgs.). Pesca e Potenciais de Exploração de Recursos Vivos na Região Central da Zona Econômica Exclusiva brasileira (Série Livros, 13). Rio de Janeiro: Museu Nacional, 2005a. p. 71-82.

KLIPPEL, S; OLAVO, G.; COSTA, P. A. S.; MARTINS, A. S.; PERES, M. B. Avaliação dos estoques de lutjanídeos da costa central do Brasil: análise de coortes e modelo preditivo de Thompson e Bell para comprimentos. In: COSTA, P. A. S.; MARTINS, A. S.; OLAVO, G. (Eds.). Pesca e potenciais de exploração de recursos vivos na região central da Zona Econômica Exclusiva brasileira (Série Livros n.13). Rio de Janeiro: Museu Nacional, 2005b. p. 83-98.
LINDEMAN, K. C.; PUGLIESE, R.; WAUGH, G. T.; AULT, J. S. Developmental patterns within a multispecies reef fishery: management applications for essential fish habitats and protected areas. Bull. Mar. Sci., v. 66, n. 3, p. 929-956, 2000

MALAFAIA, P; OLAVO, G.; FRANÇA, A.; SEARA, F.; OLIVEIRA, B.; ALMEIDA, J.; SOLEDADE, R.; ALENCAR, S.; RÊGO, L.; CASTRO, M. Experiência de Monitoramento Participativo a Bordo de Embarcações da Pesca Artesanal no Território da Cidadania do Baixo Sul da Bahia, Brasil. Desenvolv. Meio Ambiente, v. 32, p. 165-180, 2014.

MARTINS, A. S.; OLAVO, G.; COSTA, P. A. S. A pesca de linha de alto mar realizada por frotas sediadas no Espírito Santo, Brasil. In: COSTA, P. A. S.; MARTINS, A. S.; OLAVO, G. (Eds.). Pesca e potenciais de exploração de recursos vivos na região central da Zona Econômica Exclusiva brasileira. Rio de Janeiro: Museu Nacional, 2005. p. 35-55.

MARTINS, A. S.; COSTA, P. A. S.; OLAVO, G.; HAIMOVICI, M. Recursos Pesqueiros da Região Central. In: MMA, Secretaria de qualidade ambiental (Org.). Programa REVIZEE. Avaliação do Potencial Sustentável de Recursos Vivos na Zona Econômica Exclusiva. Brasília: Relatório Executivo. MMA, 2006. p. 181-206.

MARCHIORO, G. B.; NUNES M. A.; DUTRA, G. F.; MOURA, R. L.; PEREIRA, P. G. P. Avaliação dos impactos da exploração e produção de hidrocarbonetos no Banco dos Abrolhos e adjacências. Megadiversidade, v. 1, p. 225-310, 2005.

NUNES, A. S. A Utilização da Geologia na Identificação dos Hábitats mais Adequados para o Estabelecimento de Áreas Marinhas Protegidas na Costa do Dendê, Bahia. Tese de Doutorado. Salvador: Universidade Federal da Bahia, 2009.

OLAVO, G.; COSTA, P. A. S.; MARTINS, A. S. Caracterização da pesca de Linha e dinâmica das frotas linheiras da Bahia, Brasil. In: COSTA, P. A. S.; MARTINS, A. S.; OLAVO, G. (Eds.). Pesca e Potenciais de Exploração de Recursos Vivos na Região Central da Zona Econômica Exclusiva brasileira. Rio de Janeiro: Museu Nacional, 2005. p. 13-34.

OLAVO, G.; COSTA, P. A. S.; MARTINS, A. S.; FERREIRA, B. P. Shelf-edge reefs as priority areas for conservation of reef fish diversity in the tropical Atlantic. Aquatic. Conserv. Mar. Freshw. Ecosyst., v. 21, n. 2, p. 199-209, 2011

POLOVINA, J.; RALSTON, S. (Ed.). Tropical snappers and groupers: biology and fisheries management. London: Westview Press. 1987. 659 p.

SADOVY, Y. M.; CORNISH, A.; DOMEIER, M.; COLIN, P.; RUSSELL, M.; LINDEMAN, K. C. A Global Baseline for Spawning Aggregations of Reef Fishes. Conser. Biol., v. 22, n. 5, p. 1233-1244, 2008.

SADOVY, Y.; CHEUNG, W. L. Near extinction of a highly fecund fish: the one that nearly got away. Fish Fisheries, v. 4, n. 1, p. 86-99, 2003.

TEIXEIRA, S. F.; FERREIRA, B. P.; PADOVAN, I. P. Aspects of fishing and reproduction of the black grouper Mycteroperca bonaci (Poey, 1860) (Serranidae: Epinephelinae) in the Northeastern Brazil. Neotrop. Ichthyol., v. 2, n.1, p.19-30, 2004.

ZAR, J. H. Biostatistical analysis. 5th edition. New Jersey: Upper Saddle River, Pearson Education, Inc., 2010. 944 p. 